\title{
Evenk Children's Literature: History and Specific Features
}

\author{
Natalia N. Seredkina* \\ Siberian Federal University \\ 79 Svobodny, Krasnoyarsk, 660041, Russia
}

Received 22.05.2016, received in revised form 30.06.2016, accepted 14.08.2016

\begin{abstract}
The article provides an overview of the historical development of the Evenki children's literature in the context of the Evenki national literary school's total flow. The corpus of Evenki fairytales about animals is analyzed from the perspective of embodiment the peculiarities of ethnic worldview and ethnic world outlook in the artistic signs. The coexistence of a clear and simple stylistic well-formedness of the Evenki fairytales with a profound meaningful point relating the explanation of a number of natural phenomena surrounding man has been revealed. It converts seemingly children's literature to adult perception. In addition, a tendency of modeling the situation of men and nature proximity by the tools of artistic and literary images is detected. Ethnic component of the Evenki children's fairytales can be traced in the characters' description, their occupation, place of residence and food. As a rule, this is a generalized image of an Evenki or Russian as a whole. The Evenki is the one who lives in the cold, but rich in food taiga, in chum and engaged in traditional occupations: reindeer herding and fishing. The Russian is an ethnos, different from the Evenki ethnic group, engaged in animal husbandry and, at the same time, adjacent to the Evenki ethnocultural group.
\end{abstract}

Keywords: Evenki children's literature, Evenki fairytales, fairytales about animals, ethnic identity.

The study is carried out within the project "Creating a Corpus of Texts for Children in Their Native Languages (Evenki, Nenets, Nganasan and Dolgan) as a Way to Preserve the Unique Cultural Heritage of Indigenous Small Numbered Peoples of the Krasnoyarsk Territory», supported by the Krasnoyarsk Regional Science Foundation.

DOI: 10.17516/1997-1370-2016-9-9-1994-2004.

Research area: theory and history of culture.

\section{Introduction}

Fiction is one of the areas of culture, where the peculiarities of ethnic worldview are fixed and therefore, it has the ability to serve not only as a source of perception of the specific ethnic group's peculiarities of mentality, but be a factor in its selfidentification as well. This aspect is still poorly studied within the scientific literature devoted to the study of the Evenki literary school, while the analysis of the peculiarities of national fiction texts, especially children's literature gives the possibility to define certain strategies of constructing ethnic identity of ethnocultural community at the present stage of the society development.

The purpose of the study is to identify the peculiarity of children's literature of the Evenki

(C) Siberian Federal University. All rights reserved

* Corresponding author E-mail address: NevolkoN@yandex.ru 
ethnic group, to interpret literary signs as the constructs modelling the ethnic worldview and serving as a factor of the ethnos identification.

To reach the purpose the following objectives were set:

1. To study the history of the Evenki children's literature development in the general flow of the national literature development;

2. To define specific features of the Evenki children's literature exemplified by the Evenki fairytales analysis.

\section{Methods of Study}

For the purposes of studying the history of the Evenki children's literature development, historical and descriptive method, allowing to identify separate periods of the Evenki literary school development, the common features of its formation and the leading representatives has been applied. Defining the specific features of the Evenki literature requires an appeal to the analysis of specific literary texts of children's literature. In this case, the cultural-historical and hermeneutic methods are of relevance.

The cultural-historical method, one of the authors of which is a French philosopher, historian and literary critic H.A. Taine (1828-1893), and hermeneutic method (founder W. Dilthey) involve consideration of a literary work as the text of culture that contains the peculiarities of the spiritual and material culture of a particular community and its ethnocultural constants (S. Lurie).

\section{Survey of Scientific Literature on the Topic of the Article}

The problem of the Evenki literature formation lies in the center of attention of the scientists whose research interests include the culture of the indigenous small-numbered peoples of the North. Theoretical and analytical issues connected with the study of the recently put into writing literatures in the context of studying the literatures of the peoples of Siberia are considered by M.A. Bologova, L.S. Dampilova, I.V. Poltoratsky, I.V. Silantiev, et al. (2013, 2014). The authors proposed the basis for delimitation of the identified types of national literatures, gave a survey of the conducted studies in the field of the peoples of Siberia literatures. A number of entries are devoted to the review the overall picture of the Evenki literary school existence, indicating its main representatives and their works of fiction (Voskoboinikov, 1975; Khazankovich, 2009). A more detailed analysis of the Evenki literature history and development is represented in the works by Y.G. Khazankovich. The author systematizes the Evenki authors' works of fiction according to the historical and cultural situation, identifying the general tendency of the national literary school development that appears to be the valuable material for the study. The specialist in history and philology of the peoples of the North M.G. Voskoboinikov reveals the peculiarity of the Evenki oral tradition, including fairy tales, legends and oral stories, collected by the author from 1930. The author systematized all the collected material, and the Evenki fairytales, collected by the author, as the representative texts of children's literature are in particular interest for this study, according to the thematic blocks: fairytales about animals, magic fairytales, household fairytales, children's and new fairytales. The connection of the peculiarities of the Evenki literature with the conditions of its origin is revealed in the studies by N.A. Nepomniashchikh. According to the author, the works of the Evenki writers are often of essay nature, characterized by documentation and autobiographical character. They are, in a sense, the written evidence of the national world outlook, the anthropological origin of the traditional lifestyle of the indigenous people, their folklore, everyday life and culture (Nepomniashchikh, 2014). The analysis of the Evenki authors' works 
of fiction from the perspective of ethnicity issues is given in the works by E.V. Ivanova (2008), N.N. Alekseeva (2015), O.I. Pashkevich (2015) and O. Marchenko (2014). The problem of the archaic and modern worlds reflection in the prose works by the Evenki writer G. Keptuke is studied by V.B. Okorokova (2013). On the basis of the individual prose works the author constructs the image of a modern representative of the Evenki community as a person who is at the junction of two centuries, absorbing both the laws of the ancient people and the laws of a new civilization.

In general, the Evenki literature is sufficiently studied, the periods of its formation are identified and certain Evenki writers' individual works of fiction are studied, whereas the analysis of the Evenki children's literature is given insufficient attention. At the same time, children's literature genres often include serious worldview component of the ethnocultural group and therefore, require separate study and understanding.

\section{The Course of Study and Its Results}

The history of the Evenki literature development in general and children's literature in particular, is connected with the general cultural development of the ethnic community. According to Y.G. Khazankovich, "The history of the Evenki literature formation and development is a mirror projection of the national community historical path in the $20^{\text {th }}$ century" (Khazankovich, 2009). The first publications on the Evenki language date back to $19^{\text {th }}$ century. These were religious books and $\mathrm{ABC}$ books. However, these events did not have any professional support. The first literary experiences were connected with the work of the Evenki students of the 1920s that allows us, in a certain sense, to speak about the beginning of the professional Evenki literary school formation in a given period of time. Starting from this time, it is conventional to classify the events of the
Evenki literary school formation as having three main stages. These are the stage of "the Evenki literature formation" (the turn of the 1920s 1930 s - the early 1940s), the period of the 1940s early 1960 s in the history of literature is marked as a period of artistic stagnation, and a period of the Evenki literature artistic self-determination (the second half of the $60-90 \mathrm{~s}$ of the $20^{\text {th }}$ century).

The first stage of the Evenki literature development is full of significant events. First of all, due to the absence of writing the Evenki literature developed within the framework of oral tradition. There was a group of storytellers "nimngakalan" (specialist in fairytales telling) and "davlalan" (specialist in songs singing) that recited the folklore content (Voskoboinikov, 1973). At this stage, it was characteristic to refer to the following genres:

1. Fairytale - nimngakan (nimngakavun, nimngakachivun) that, in turn, comprised the following types or groups of fairytales:

1) fairytales about animal;

2) magic tales;

3) epic heroic tales;

4) household tales;

5) fairytales for children;

6) new fairytales.

2. Heroic epic - ulgur (uliger).

3. Legends - urguril.

4. Songs:

1) song-dance or circle dance ikevun;

2) song-improvisation and choruses in ulgurs, various tongue twisters - hegevun (egevun);

3) song-improvisation and song with the constant song lyrics (davlavun).

5. Riddle - nenevke (nenevkevun, nenevkechivun, tagivka).

6. Counting rhyme - tangivka.

7. Proverb and saying - gumenk (gumunvke).

8. Shamanic chants - saman nimnganin.

9. Charms. Spells. 
10. Ethnographic omens based on superstition and practical knowledge of nature.

Simultaneously with the oral folklore development the first handwritten editions with the texts of the Evenki writers, such as Khunt Elpin, Yukagir Spiridonov (Teki Odulok) and Evenki Salatkin and Nerguneev appear. Since the young writers were the authors, the content of the texts was also aimed at the youth and student audience. The first representations of the Evenki literature were student magazines "Taiga and Tundra" (1928, 1933), the collections of student stories "About Our Life" (1929) and literary anthologies "Before and Now" (1938).

In 1933 the first fiction in the Evenki language - a story by Naumov "How I Killed the Elk" was published as a book by the publishing house "Molodaia Gvardiia". The classic works of the Evenki literary schools were created. The story "Red Suglan" (1938) and chapters of the novel "Margesha's Dreams Come True" by Nikita Sakharov are among them.

The linking period between the two key stages of the Evenki literature development was the period of the 1930-1940s, characterized by mass repressions, interdiction of many writers from their creative activity and manuscripts disappearance. Nevertheless, the works continued to be created. The poems by Ivan Kirillov, Afanasy Khromov, N. Petrov, S. Monokonov and V. Soloviev; an autobiographical novel by P. Savin "The Second Birth", an autobiographical story by N. Lamatkanov "Kachona" and a story by G. Konenkov "Alena Uvachan's Family" became these representatives. One of the peculiarities is the tendency of autobiography and personal expression of feelings through the prism of fiction characters.

The third phase (the 1960-1990s) is characterized by the revival of the Evenki literature. The form and content of literary texts changed. At this stage, the classics of the
Evenki literature create their works. The poets Alitet Mikhailovich Nemtushkin, Dmitry Aprosimov and Nicholai Oegir and writer Galina Varlamova-Keptuke are among them. Literary works of different genres are created: poems, including poems for children - "Kunakardu" ("For Children") by A.N. Myreeva, stories, short stories, fairytales and novels. In addition, in 1995 in Stockholm, in the Institute for Bible Translation, an Evenki scientist-linguist and folklorist A.N. Myreeva translated "The Stories of God" into the Evenki language. The main idea of each of the genres was the idea of understanding the fate of the people. Ethnic theme at this stage acquires new understanding, characterizing a fundamentally new step in the development of not only the Evenki literature, but also the literatures of the peoples of the North in general.

The peculiarity of the Evenki literature development is the fact that the works of the Evenki writers coexisted both in the Evenki and the Russian languages. The knowledge of the Russian language was considered the norm for the Evenki authors. In addition, it gave opportunity to enter into the general mainstream of the literary process development on the whole. In particular, the poems of the Evenki Davlan-Nerguneev and "The Legend of Ermak" by A. Achkina were published in the Russian language. The development of the Evenki literary schools contributed to the written literary Evenki language formation. The coexistence of the Russian and Evenki languages is a specific feature of the national literary process development. Not only the works of the Evenki authors were published in the Russian language, but the masterpieces of the Russian literature found their embodiment, the "second life" in the Evenki language. Thus, A. Platonov did the first translation of the poem by A. Pushkin "The Monument" into the Evenki language, in 1939 N. Sakharov and A. Salatkin translated "Old Isergil" by M. Gorky into the native language, A.P. Savin 
translated "Stories" from "The ABC Book" by L. Tolstoy, A. Nemtushkin translated "The Tale of the Fisherman and the Fish" by A.S. Pushkin into the Evenki language. Poems for children by the Soviet authors A. Barto and S. Marshak were translated into the Evenki language.

In general, the history of the Evenki children's literature development is inextricably connected with the general tendency of the national school development. Children's literature had been developing throughout the development of the Evenki literature and was also connected with the general cultural situation. The empirical material for the children's literature genres creation: fairytales, poems, stories and novels was folklore, legends and traditions recorded by the Evenki writers.

In order to understand the specific features of the Evenki children's literature it is necessary to appeal directly to the texts of the national school of the children's literature. Fairytale is one of the most representative genres of the children's literature. This genre is rather widely developed in the Evenki literary school. A huge number of fairytales were written for the children of different ages. There are fairytales for the smallest children from 0 to 3 years; there are fairytales with the more expanded storylines for older children from 4 to 10 years. This division is based on our author's perception of the Evenki fairytales content, there are no age restrictions set by the fairytales authors. Evenki fairytales were the result of the national authors' collecting activities. Vasily Silich Pezhemsky was one of the first who started collecting and processing the Tunguska folklore. Thanks to his findings in 1937-1938 the separate editions of "The Evenki Fairytales" and "About the Fox: the Evenki Fairytales" were published. M.G. Voskoboinikov has the great merit in systemization and interpreting the Evenki fairytales, and fairytales collected by him have become the object of this study. In particular, the Evenki fairytales about animals have been used for the analysis.

According to Voskoboinikov's comment, fairytales about animals, or, as they are usually called in folklore, beast fables, are one of the common types of the Evenki fairytales (Voskoboinikov, 1973). Fairytales about animals are relevant both for children and adult population. On the one hand, these are small fairy tales that occupy from 0.5 to 2.5 book pages, with simple storylines and with two or three characters, what is available for the children's perception, and on the other hand, from the point of view of their ideological component, these fairytales become cautionary tales both for the older children and for adult population. Among these ideas it is possible to highlight the idea of deception and its disclosure (fairytales "The Fox and the Little Bird", "How the Birds Appeared" and "How the Fox Deceived the Women") and explaining some laws of nature through the fairytale. The "speaking" titles of fairy tales, for example, "Why the Fox Became Red", "Why the Tips of the Hares' Ears are Black" are a proof of it. In addition, the fairytales of this type always end with some summarizing phrase that gives an answer to the title of the fairytale:

The River says, "Stop drinking the water, I will extinguish the Fox". It extinguished the Fox. Since that time the Fox became red. And now it is red. ("Why the Fox Became Red");

The Sluggard hit the Hare's ears, and they immediately turned black. That is why now the tips of the hares' ears are black. ("Why the Tips of the Hares' Ears are Black');

The Evenki women do not like foxes for that, and the foxes avoid the women like the plague. ("How the Fox Deceived the Women");

The Bear got angry and hit the Crucian Carp with his paw. Previously, all the crucian carps were round. And now, after the Bear's attack, they became flat. Every Evenki old man 
remembers this. ("The Bear and the Crucian Carp"), etc.

Such endings of the Evenki fairytales demonstrate the ancient mythological Evenki representations of animals. These are a kind of person's attempts to explain natural phenomena. The presence of explanations in the form of a fairytale gives evidence of the Evenki's sensitivity to the processes and phenomena that occur in nature, in particular, to the habits of fish, animals and birds that live in the taiga and tundra.

In addition to the aforementioned fairytales such fairytales about animals as "The Fox and the Little Bird", "How the Birds Appeared", "How the Fox Deceived the Women", "The Fox", "The Fox and the Bear", "The Bear and the Chipmunk", "The Bear and the Crucian Carp", "The Swan" and "The Wood Grouse and the Black Grouse" have been analyzed.

Small size of fairytales about animal gives opportunity to analyze them as a unified whole, identifying common and typical components of these literary texts. Such components of analysis and further interpretation are:

- characters;

- storyline;

- literary signs that represent ethnic world outlook.

The leading character in the Evenki fairytales about animals, as well as in the other Tungusic peoples, is the fox. Fairytales with this character in most cases have the same storyline that allows us to speak about a single cycle called by M.G. Voskoboinikov the poem "about the adventures of the cunning and insidious fox" (Voskoboinikov, 1973, P.10). In different fairytales the fox appears as a cheating and stealing character. The storyline is built around the theme of deception. Cheating allows the fox to possess either nestlings or things. However, this deception is revealed, and the fox is punished for it. It definitely contains instructive moment important for the honest person upbringing. The inhabitants of the different natural spaces: the forest taiga (the bear, the hare and the squirrel), air (the little bird, the swan, the wood grouse and the black grouse), and sea animals (the crucian carp) are accompanying characters. In short, the "geography" of the characters in the Evenki fairytales is quite diverse, covering various aspects of natural life. At the same time, the nature itself is one of the characters. The Fox can have a dialogue with the river, such as in the fairytale, "Why the Fox Became Red":

The Fox ran and came to the River. The Fox says,

"Extinguish it, River"!

The River answered,

"I will not. The water is not enough. I only give water to the stones".

The Fox says,

"I will say the horses to drink you up".

Impersonation of nature emphasizes the closeness of all life to the natural origin, a kind of their unity. At that, it does not matter whether it is a man or an animal. Nature often acts as a regulator of events that guide the action for the better.

Along with the characters animals and nature, man plays the important role in the fairytales. However, if in the Western Evenki's fairytales the main character is the fox, in the Eastern, in particular, Sakhalin Evenki's fairytales story telling includes the episodes of man's struggle with the fox, i.e., the man acquires a dominant position. The point that it is a generalized image as, as a rule, there are no specific names, is considered important. This is grandmother in general - the Evenki woman, the Evenki, the old man and the old woman, the Russian woman and the man. Thus, the character's belonging to the human race is specifically emphasized. Quite often the reader's attention is focused not 
so much on the character's name, but his/her ethnicity. Whether he/she is Evenki or Russian, for example. This point becomes the leading one in the process of the character's identification in the Evenki fairytales about animals. How do animals communicate with nature and the character-man is not an exception. He/she does not live only in the community of their own kind, he/she also enters into a dialogue one day with the nature, another day with the animals. This also evidence of the unity of the natural and by now, the human.

The Grandmother felt asleep. The Fox stole her necklace and went away. The grandmother woke up, found no necklace and began to cry. The Bird came and said,

"Why are you crying?"

The grandmother answered,

"The roguish Fox was here, it began to search in my head, I felt asleep and it stole my necklace, that is why I cry" ("How the Birds Appeared").

In addition, the ethnic factor is also manifested in the description of the characters' place of residence, their occupation and food. Chum is always the place of residence, located in the taiga. The taiga is characterized as a cold and frosty place, a place with snow, but, at the same time, rich in food: "There is enough space and food for it (the Wood Grouse) in the taiga. It is not afraid of frosts. It sleeps in the snow. And it is warm for the Wood Grouse to sleep in the snow, as well as for the man in a good chum" ("The Wood Grouse and the Black Grouse"). The characters' occupation is connected with the traditional Evenki production activity, with reindeer herding, hunting, fishing, reindeer migrations, procuring food and tools manufacture. The characters' food is usually fat reindeer meat.

One of the specific features of the Evenki fairytales is the coexistence of the elements of Russian identity along with the signs manifesting the peculiarity of the Evenki ethnic identity. Fairy tale "The Fox" is one of the representative Evenki tales in this regard. Along with the fox, the characters in this fairytale are the old man and the old woman, the Russian women, the Russian man on a horse sleigh and the Russian people in general. Ethnic background of the old man and the old woman is seen through the description of their occupation: "There lived an old man and an old woman and they had not many deer. The old man went hunting and the old woman herded reindeer". The initial story line revolves around the fox hunting for the herd of the elderly couple's deer, and then the focus shifts to the storyline borrowed from the Russian folk tale "The Fox and the Grey Wolf". Russians in this context are presented as the people involved in cattle breeding: "Go to the water hole, where the Russians take water for the cattle. ... In the meantime, the Russian women were going for water".

On the whole, having analyzed the corpus of the Evenki children's fairytales about animals the following specific features of this genre of the Evenki children's literature can be emphasized:

1. The Evenki children's literature developed in line with the general tendency of the Evenki literary school formation. It is a separate part of the Evenki literature that requires its study and understanding not only as the representative children's literature of this national school, but also in the context of understanding the ethnic outlook, embodied in the artistic signs of the literary works.

2. One of the representative genres of the Evenki children's literature is the fairytale that incorporates the folklore features of the Evenki ethnocultural group.

3. Small volume, limited number of characters, clear storyline and simple syntax make the Evenki fairytale available for children's perception. 
4. The presence of the profound meaningful moments over the apparent simplicity, in particular explanation of a number of natural phenomena surrounding man and revealing the concept of "deception" endows the fairytale with pedagogical, educational and ideological functions. It converts the seemingly children's fairytale to the adult world perception.

5. Embodiment of nature, the presence of the situations of dialogue between men and animals models the unity of natural and human principles, the proximity of man to nature.

6. The presence of ethnic moment in the fairytales is traced in the characters' characteristics, their occupations, place of residence and food. As a rule, it is a generalized image of either Evenki or Russian. The Evenki is the one who lives in the cold, but rich in food taiga, in chum and engaged in traditional occupations: reindeer herding and fishing. The Russians is the ethnos, different from the Evenki ethnic group, engaged in animal husbandry.

\section{References}

Alekseeva, N.N. (2009). Etnopoeticheskoe svoeobrazie prirodnogo i veshchnogo mira v literature narodov Sibiri (na materiale buriatskoi, evenkiiskoi, iakutskoi poezii i prozy) [Ethnic and Poetic Originality of the World of Nature and Material World in the Literature of the Peoples of Siberia (Exemplified by Buryat, Evenks and Yakut Poetry and Prose)]. Dissertation for the Degree of the Candidate of Philological Sciences. Ulan-Ude.

Alekseeva, N.N. (2015). Etnopoeticheskaia soderzhatel'nost' obrazov puti, dorogi, tropinki v evenkiiskoi poezii [Ethnopoetic Content of the Concepts of Way, Road and Track in the Evenki Poetry], In Sotsiosphera [Sociosphere], 9, 94-96.

Bologova, M.A., Dampilova, L.S., Poltoratsky, I.V. et al. (2014). Literatury korennykh narodov Sibiri v aspekte teoreticheskoi i istoricheskoi poetiki [Literatures of the Indigenous Peoples of Siberia in the Context of Theoretical and Historical Poetics], In Philologiia i chelovek [The Philology and a Person], 3, 57-64.

Brzakova, P., Voronov, V. (2000). Goromomo-gorolo. Davnym-davno: evenkiiskie skazki, legendy, skazaniia [Goromomo-gorolo. Once Upon a Time: Evenki Fairytales, Legends and Epics]. Krasnoyarsk, Sibirsky Promysel Publishing, 157 p.

Ivanova, E.V. (2004). Etnicheskoe kak put' k obshcherossiiskomy (po stranitsam evenkiiskoi literatury kontsa XX veka) [Ethnic as a Way to All-Russian (Through the Pages of Evenk Literature of the Late $20^{\text {th }}$ Century)], In Real'nost' etnosa. Obrazovanie i natsional'naia ideia. Materialy VI Mezhdunarodnoi nauchno-prakticheskoi konferentsii. Nauchnyi redactor I.L. Nabok [Ethnos Reality. Education and National Idea. Proceedings of the $6^{\text {th }}$ International Scientific and Practical Conference. Science Editor I.L. Nabok], 425-427.

Ivanova, E.V. (2006). Fol'klornye istoki v tvorchestve evenkiiskoi pisatel'nitsy G. Keptuke [Folklore Origins in the Works of Evenki Writer G. Keptuke], In Izvestiia Rossiiskogo gosudarstvennogo pedagogicheskogo universiteta im. A.I. Gertsena [Izvestia: Herzen University Journal of Humanities \& Science], 3 (20), 21-24.

Ivanova, E.V. (2008). Sotsio-etnicheskie problemy istorii evenkiiskoi literatury [Social and Ethnic Problems of the Evenki Literature History]. Dissertation for the Degree of the Candidate of Philological Sciences. Saint-Petersburg.

Kistova, A.V. (2013). Stanovlenie philosophii kul'tury kak metodologicheskoi osnovy gumanitarnogo znaniia [Establishment of Philosophy of Culture as a Methodological Basis of 
Humanitarian Knowledge], In Sovremennye problemy nauki i obrazovaniia [Problems of Modern Science and Education], 1, 401.

Kolesnik, M.A. (2014). Obzor izucheniia fol'klora korennykh narodov Severa [Survey of the Studies of Folklore of the Indigenous Peoples of the North], In Litera, 3, 9 - 11.

Koptseva, N.P. (2014). K voprosu o gosudarstvennoi politike v oblasti sokhraneniia iazykov korennykh malochislennykh narodov Severa [To the Issue of State Policy in the Field of Preservation the Languages of the Indigenous Small-Numbered Peoples of the North], In Arktika i sever [Arctic and North], 16, 34-40.

Koptseva, N.P., Seredkina, N.N. (2013). Konstruirovanie pozitivnoi etnicheskoi identichnosti v policul'turnoi sisteme [Formation of Positive Ethnic Identity in Multicultural System]. Krasnoyarsk, Siberian Federal University.

Koptseva, N.P., Nevol'ko, N.N., Reznikova, K.V. (2013). Formirovanie etnokul'turnoi identichnosti v sovremennoi Rossii s pomoshch'iu proizvedenii natsional'nogo iskusstva (na primere evenkiiskogo eposa i dekorativno-prikladnogo iskusstva) [Ethnocultural Identity Formation in Modern Russia through the Use of the Works of National Art (Through the Example of Evenk Epos and Applied and Decorative Arts)], In Pedagogika iskusstva [Pedagogics of Art], 1, 1-15.

Koptseva, N.P., Sertakova, E.A., Il'beikina, M.I., Zamaraeva, Y.S., Libakova, N.M., Bakhova, N.A., Luzan, V.S., Reznikova, K.V., Kistova, A.V., Pimenova, N.N., Nevol'ko, N.N. (2011). Kul'tura korennykh i malochislennykh narodov Severa v usloviiakh global'nykh transformatsii [Culture of the Indigenous and Small-Numbered Peoples of the North under Conditions of Global Transformations]. Saint-Petersburg. 174 p.

Koptseva, N.P., Bralkova, A.V., Gerasimova, A.A., Govorukhina, Y.A., et al. (2015). Novaia artkritika na beregakh Eniseia [New Act Criticism at the Banks of the Yenisei]. Krasnoyarsk, Siberian Federal University.

Libakova, N.M., Sertakova, E.A. (2014). Kul'turologicheskoe issledovanie korennykh malochislennykh narodov Severa Krasnoyarskogo Kraia: rezul'taty ekspertnogo interv'iu [Culturological Study of Indigenous Small-Numbered Peoples of the North of the Krasnoyarsk Territory: Expert Interview Results], In Sovremennye problemy nauki i obrazovaniia [Problems of Modern Science and Education], 4, 598.

Marchenko, O. (2014). Kul'turovedcheskii i etnokul'turnyi podkhody k izucheniiu fol'klora narodov Sibiri [Culturological and Ethnocultural Approaches to the Study of Folklore of the Peoples of Siberia], In Russkii iazyk v natsional'noi shkole [Russian Language in the National School], 1, 14-25.

Nepomniashchikh, N.A. (2014). Chelovek na perekrestke kul'tur: evenkiiskaia literatura v sovremennom mire [Man at the Crossroads of Cultures: the Evenki Literature in the Modern World], In Antropologicheskie sdvigi perelomnykh epoch I ikh otrazheniie v literature [Anthropological Shifts of Critical Epochs and Their Reflection in Literature], 45-51.

Nepomniashchikh, N.A. (2014). Evenkiiskaia literatura: spetsifika zenezisa i bytovaniia, tipicheskie ciuzhety i motivy [Evenk Literature: Specific Features of Genesis and Existence, Typical Storylines and Motives], In Sibirskii philologicheskii zhurnal [Siberian Philological Journal], 4, 75-82.

Oegir, N.K. (2006). Chtob ne gas koster: evenkiiskie narodnye skazki, zagadki, primety, nastavleniia, stikhi [In Order Not Let the Fire Out: Evenki Folk Tales, Riddles, Sayings, Guidance and Poems]. Krasnoyarsk, Sibirskie Promysly, 350 p. 
Okorokova, V.B. (2013). Problema arkhaichnogo i sovremennogo mira v proze G. Keptuke [Problems of Archaic and Modern World in the Prose by G. Keptuke], In Lingvisticheskie, kul'turologicheskie $i$ didakticheskie aspekty kommunikatsii $v$ polikul'turnom prostranstve [Linguistic, Cultorological and Didactic Aspects of Communications in Multicultural Space], 322-333.

Peshkevich, O.I. (2015). Osobennosti otrazheniia natsional'nogo mentaliteta v tvorchestve Nikolaia Kalitina [Peculiarities of National Mentality Reflection in the Works by Nikolai Kalitin], In Vysshaia shkola [The High School], 6, 29-30.

Pimenova, N.N. (2014). Kul'turnoe nasledie korennykh malochislennykh narodov Krasnoyarskogo kraia i sovremennye kul'turnye praktiki [Cultural Heritage of Indigenous Small-Numbered Peoples of The Krasnoyarsk Territory and Modern Cultural Practices], In Chelovek i kul'tura [Man and Culture], 2, 28-66.

Pimenova, N.N. (2015). Korennye malochislennye narody v sovremennoi situatsii: ob"em i soderzhanie poniatiia [Indigenous Small-Numbered Peoples in the Modern Situation: Scope and Content of the Concept], In Sotsiodinamika [Sociodynamics], 1, 112-134. DOI: 10.7256/2409-7144.2015.1.14249. Available at: http://e-notabene.ru/pr/article_14249.html

Poltoratsky, I.V., Silantiev, I.V., Shirokobokova, N.N. (2013). Nekotorye teoreticheskie aspekty izucheniia mladopis'mennykh literature [Some Theoretical Aspects of Studying Recently Put into Writing Literatures], In Sibirskii philologicheskii zhurnal [Siberian Philological Journal], 4, 124-131.

Razumovskaya, V.A. (2012). Izomeriia v lingvistike i perevodovedenii: rasshirenie kategorial'noi paradigmy [Isomerism in Linguistics and Translation Studies: Categorical Paradigm Extension], In Iazyk i kul'tura [Language and Culture], 4 (20), 49-61.

Razumovskaya, V.A. (2015). Kognitivnye osobennosti avtorskogo perevoda poezii [Cognitive Features of Poetry Self-Translation], In Kognitivnye issledovaniia iazyka [Cognitive Language Studies], 22, 521-523.

Reznikova, K.V. (2014). K voprosu ob utochnenii poniatii "etnos" i "etnichnost" [The Question of Specification of the Concepts "Ethnos" and "Ethnisity"], In Sotsiodinamika [Sociodynamics], 12, 90-102. DOI: 10.7256/2409-7144.2014.12.13913. Available at: http://e-notabene.ru/pr/article_13913.html

Reznikova, K.V.(2016). K voprosu ob epicheskom kul'turnom nasledii korennykh malochislennykh narodov Krasnoyarskogo kraia [The Question of Epical Cultural Heritage of Indigenous SmallNumbered Peoples of the Krasnoyarsk Territory], In Litera, 2, 20-34.

Sitnikova, A.A. (2014). Khudozhestvennaia interpretatsiia obraza zhizni na Severe v proizvedeniiakh Rokuella Kenta [Artistic Interpretation of the Way of Life in the North in the Works by Rockwell Kent], In Sovremennye problemy nauki i obrazovaniia [Problems of Modern Science and Education], 4, 593.

Khazankovich, Y.G. (2009). Literatura i knizhnaia kul'tura evenkov: k istokam orozhdeniia [Literature andBookCulture of The Evenks: to the Origins], In VestnikZabaikal'skogo gosudarstvennogo universiteta [Bulletin of Zabaikalsk State University], 2, 176-181.

Khazankovich, Y.G. (2009). Funktsionirovanie evenkiiskogo fol'klora v povesti Galy Keptuke "Imeiushchaia svoe imia Dzheltuna-Reka" [Evenki Folklore Functioning in the Story by Gala Keptuke "The Geltula-River That Has Its Own Name"], In Traditsionnaia kul'tura [Traditional Culture], 1, $81-85$. 
Khazankovich, Y.G. (2009). Evenkiiskaia literatura: problemy pereodizatsii [Evenki Literature: Periodization Problems], In Izvestiia Rossiiskogo gosudarstvennogo pedagogicheskogo universiteta im. A.I. Gertsena [Izvestia: Herzen University Journal of Humanities \& Science], 108, 99-109.

Khazankovich, Y.G. (2014). Kul'tura i literatura malochislennykh narodov Arktiki: "Vlast' traditsii" [Culture and Literature of Small-Numbered Peoples of the Arctic Region: "The Power of Tradition"], In Vestnik Severo-Vostochnogo federal'nogo universiteta im. M.K. Ammosova [Bulletin of North-Eastern Federal University Named After M.K. Ammosov], 11 (1), 142-149.

Evenkiiskaia literatura. Istoricheskaia entsiklopediia Sibiri [Evenki Literature. Historical Encyclopedia of Siberia]. Available at: www. irkipedia.ru

Evenkiiskaia literature. Kratkaia literaturnaia entsiklopediia [Evenki Literature. Brief Literary Encyclopedia]. (1975). (8). Available at: www.feb-web.ru

Evenkiiskaia literatura: uchebnaia khrestomatiia [Evenki Literature: Studies Reader]. Comp. by E.F. Afanas'ev, A.A. Voronin (2006). Ulan-Ude, Buryat University Publishing House.

\section{Эвенкийская детская литература: история и специфика}

Н.Н. Середкина

Сибирский федеральный университет Россия, 660041, Красноярск, пр. Свободный, 79

Статья посвящена обзору исторического развития эвенкийской детской литературы в контексте общего потока развития национальной литературной школь эвенков. Анализируется корпус эвенкийских детских сказок о животных с позиции воплощения в художественных знаках особенностей этнической картины мира, этнического мировоззрения. Выявлено сосуществование ясной и простой стилистической оформленности эвенкийских сказок с глубоким содержательным моментом, касающимся объяснения ряда окружающих человека природных явлений. Это преобразует, казалось бы, детскую литературу до взрослого мировосприятия. Кроме того, выявлена тенденция моделирования средствами художественно-литературных образов ситуации близости человека и природы. Этническая составляющая эвенкийских детских сказок прослеживается в характеристике персонажей, их рода деятельности, месте жительства, пище. Как правило, это собирательный образ эвенка либо русского в целом. Эвенк - это тот, кто живет в холодной, но богатой пропитанием тайге, в чуме, занимается традииионными видами деятельности: оленеводством, рыболовством. Русский - это отличный от эвенкийской этногруппы этнос, занимающийся скотоводством и в то же время соседствующий с эвенкийской этнокультурной группой.

Ключевые слова: детская эвенкийская литература, эвенкийские сказки, сказки о животных, этническая идентичность.

Статья написана при выполнении исследований по гранту Красноярского краевого фонда поддержки научной и научно-технической деятельности на тему: «Создание корпуса текстов для детей на родных языках (эвенкийский, ненеикий, нганасанский, долганский) как способ сохранения уникального культурного наследия коренных малочисленных народов Красноярского края».

Научная специальность: 24.00.01 - теория и история культуры. 